\title{
Labor Market Need Analysis as Basis for the Foundedness of Occupational Standards in the Field of Maritime Management
}

\author{
Merica Slišković, Helena Ukić, Eli Marušić
}

This paper presents the results of a maritime sector labor market research conducted to identify key tasks, specific knowledge and skills required for the development of appropriate occupational standards in the field of maritime management. Data were collected by survey of a sample of potential employers for the professions of "Manager in Marinas and Nautical Tourism" and "Maritime Personnel Training and Education Coordinator". Research results indicate both professions are recognized by prospective employers and that appropriate standards need to be developed.

\section{KEY WORDS}

$\sim$ Labor market

$\sim$ Maritime sector

$\sim$ Key tasks

$\sim$ Standard in the field of maritime management

\section{INTRODUCTION}

From 19 June 2015 to 18 September 2016, the Faculty of Maritime Studies, the University of Split, will be the holder of a HRK 1,950,924.34 ( $€ 256$ 700) worth project "Maritime Management for the $21^{\text {st }}$ Century - Sustainable and Intelligent Development of the Coastal Area through the Development of Occupational and Qualification Standards in the field of Maritime Management and the Enhancement of Corresponding Graduate University Programs", in the framework of the European Social Fund grant scheme "Raising the Quality of Higher Education through the Implementation of the Croatian Qualifications Framework". In cooperation with project partners - the Port Authority of the Split-Dalmatia County, Plovput, the Croatian Employers' Association, B4 Association and companies Nautika centar Nava, Marina Kaštela and Bav-Adria Yachting, this project is intended to promote the recognizability of professions and qualifications from the field of maritime management on the labor market. By establishing relations with key partners from the maritime sector and developing the skills of professors from the Faculty of Maritime Studies relevant for the application of the Croatian Qualifications Framework through the development of occupational standards and modernization, the Maritime Management study program will correlate with and become more responsive to the needs of the labor market.

The implementation of the above project is compatible with the goals of the Strategy of Education, Science and Technology of the Republic of Croatia - New Colors of Knowledge, and in this part with Goal 1 - The improvement of study programs through the systematic application of the tenets of the Bologna reform and the redefinition of acquired competences. 
The Croatian Qualifications Framework (CQF) is an instrument regulating the Croatian education and lifelong learning system. One of the principal tasks of the CQF is to correlate the needs of the labor market with educational programs at all levels. Occupational and qualification standards are the key tools for achieving such correlation. Learning outcomes are the key link between occupational and qualification standards. They include both knowledge and skills, i.e. competences acquired through learning and proven by appropriate tests, defined on the basis of knowledge and skills determined by the applicable occupational standard. Thus, quality occupational standards containing key information on employers' needs, the content of a profession and workplace specification are the basis of quality educational programs responsive to employers' needs, whereby the employers are given an important role in the creation of educational programs and a direct correlation is established between the educational system and the needs of the labor market.

The occupational standard relevance analysis rests on strategic and analytical basis. The analytical basis for the development of an occupational standard includes the profiling of the sector of the respective profession and labor market research by a survey of potential employers concerning that profession. Owing to the importance of surveys for the labor market in general, they are envisaged by the National Reform Program (3.3.2., pg. 25), and conceived so as to allow standardized gathering of data for a variety of professions from an array of employers.

\section{RESEARCH GOAL AND METHOD}

\subsection{Goal}

The goal of this research was to use survey to collect data from employers on key tasks, as well as on the knowledge and skills required for the performance thereof, for the professions of "Manager in Marinas and Nautical Tourism" (hereinafter: Manager) and "Maritime personnel Training and Education Coordinator" (hereinafter: Coordinator). Such data, as well as the data collected by additional methods, at the meetings of the Occupational Standard Taskforce, are the grounds for defining occupational standards.

\subsection{Research Method}

The labor market research process, including the questionnaire used to collect data, was developed by the Ministry of Labor and the Pension System and the Croatian Employment Bureau, while the research was conducted in the framework of the "Maritime Management for the $21^{\text {st }}$ Century" project of the Faculty of Maritime Studies in Split. The research was conducted in the form of an online survey in the period 20 September-15 November 2015. The respondents $(\mathrm{N}=289)$ were surveyed by e-mail containing a link to the online questionnaire. The respondents who failed to fill-out the questionnaire within a week were sent an e-mail reminder and those failing to fill it out within two weeks were contacted by phone.

The question Description of key tasks and specific knowledge and skills, requiring the employers to indicate 5 key tasks for the proposed occupational standards and rank them by importance, constituted the main part of the questionnaire. Having defined key tasks, the employers were asked to indicate which specific knowledge and skills they considered necessary for the performance of such key tasks. Instructions to employers stressed that the answers would best be provided by a company employee most familiar with the requirements of the workplace in question (e.g. immediate superior, human potentials officer and similar), to ensure that the most knowledgeable reply is obtained.

A separate part of the questionnaire examined key competences for lifelong learning. Generic (transversal, transferrable) skills are those considered necessary in a wide variety of professions, which can therefore be used or "transferred" by an individual across different areas of professional life. They concern the 2006 EU recommendation on competencies for social inclusion, employment, development and lifelong learning. 8 such competences were identified, all of which were examined by the questionnaire.

\section{RESEARCH RESULTS}

The questionnaire was sent to a total of 289 companies in the Republic of Croatia, with project partners greatly contributing to the selection of key employers to be included in the research. Out of a total of 289 questionnaires sent, 60 were filled-out completely, 27 for the profession Maritime personnel Training and Education Coordinator and 33 for the profession Manager in Marinas and Nautical Tourism.

\subsection{Required Qualification Level}

In this set of questions, the employers were also asked to indicate the required level of education, i.e. qualification level they considered most suitable for a particular profession, with $20(52.6 \%)$ out of 38 replies indicating that the profession of Manager necessitated graduate university studies (Level 7). As for the profession of Coordinator, 31 employers answered the question, with 12 employers (38.7\%) indicating that Level 6, i.e. undergraduate university studies was required, and 5 (16.1 $\%$ ) being of the opinion that any undergraduate professional program (Level 6) would be appropriate. The diagram of collective data is provided in Figure 1. 
Level 7: post-Master specialist university studies

Level 7: specialist graduate professional studies

Level 7: graduate university studies

Level 6: undergraduate professional studies

Level 6: undergraduate university studies

Level 5: professional higher education studies with less than 180 ECTS

Level 4.2: four-year and five-year vocational secondary education;

Level 4.2: general secondary education

Level 1: primary education;

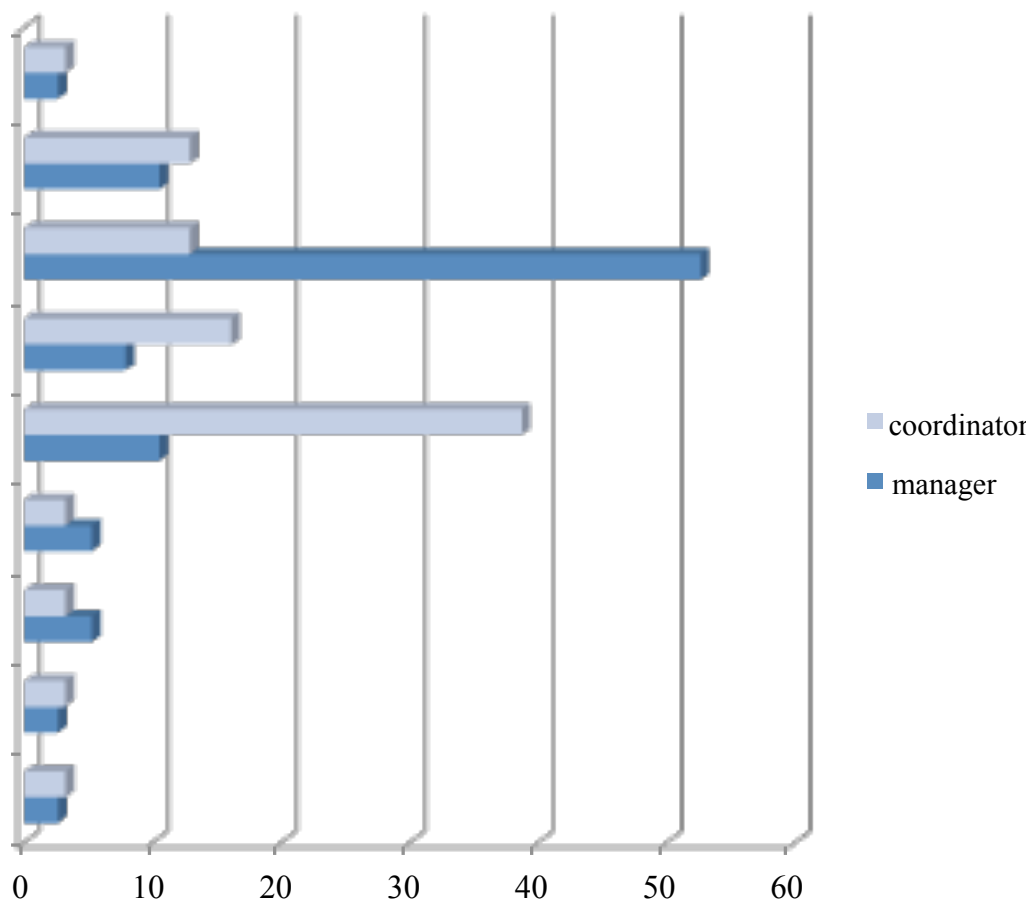

Figure 1.

Diagram of required qualification levels for 2 professions - Manager in Marinas and Nautical Tourism and Maritime personnel Training and Education Coordinator.

\subsection{Key Tasks, Specific Skills and Knowledge}

The central part of the questionnaire was a set of questions on the key tasks performed by employees at respective workplaces, as well as on the key knowledge and skills required for the successful execution of such tasks. The questionnaire contained a selection of key tasks among which employers were required to indicate those they considered relevant for each workplace. The employers were also asked to rank key tasks by importance. In the same vein, the employers could choose up to 5 skills and knowledges for each task from the selection they believed to be essential for the successful execution of each task.

\subsubsection{Key task analysis}

A total of 36 employers $(\mathrm{N}=36)$ replied to questions on key tasks for the profession of Manager. 32 respondents (88.9 $\%)$ indicated communication and coordination with external (partners, guests) and internal (employees) stakeholders as the most important key task. Other data are illustrated in Figure 2.

27 employers replied to questions on the key tasks for the second profession, that of the Coordinator, with 21 (77.8\%) indicating Coordination and organization of specialized training programs and Cooperation with competent national authorities and international training service providers as the two most important tasks. 

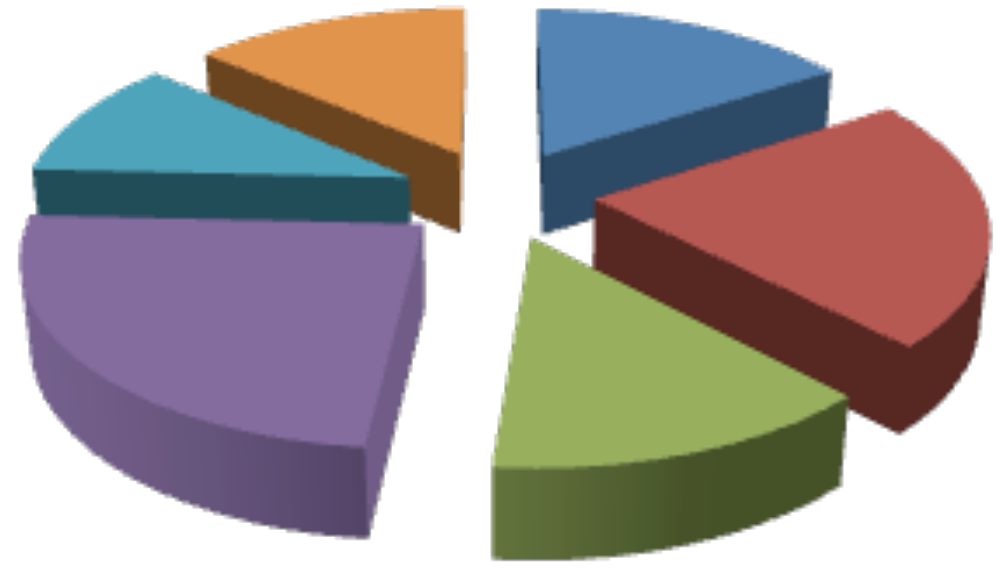

- Management of technical processes in the marina

- Marina business management and activities

- Financial and strategic planing of the marina

Communication and coordination with external(partners,guests) and internal

(employees) stakeholders

- Protection of sea and sea environmnet

Improving the knowledge in maritime law and other relevant regulations

Figure 2.

Key tasks - profession Manager in Marinas and Nautical Tourism.

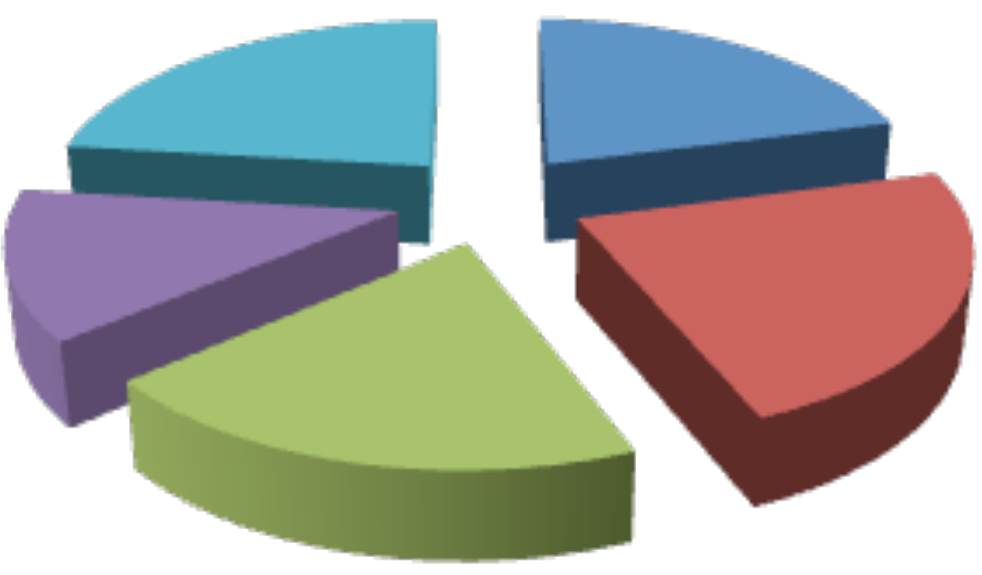

Monitoring the need for education and training of new and existing maritime personnel

Coordination and organization of specialized training programs

- Administration and maintainince of educational programs data

Education programs cost management

Cooperation with competent national authorities and international training services providers

Figure 3.

Key tasks - Maritime personnel Training and Education Coordinator.

\subsubsection{Correlation between key tasks and the knowledge and skills for the occupational standard of Manager in Marinas and Nautical Tourism}

For the occupational standard of Manager in Marinas and Nautical Tourism the employers were asked to rank the key tasks by importance and chronologically link them with the knowledge and skills they considered necessary for the performance of the respective task. Namely, the respondents indicated the knowledge and skills required of employees for each key task, i.e. everything an employee must know and be able to do to successfully perform the task in question. The employers also estimated to what extent the respective skills were taught in the course of formal education and to what extent they were the combination of education and work experience. With the offered knowledge and skills, every employer was able to bring other competences considered relevant for the performance of certain key job. These states are also analyzed and included in the results. 
Table 1.

Knowledge and skills for the first key task .

Managment of tehnical processes in the marina

MANNER OF KNOWLEDGE AND

\begin{tabular}{|c|c|c|c|}
\hline & \multicolumn{3}{|c|}{ SKILL ACQUISITION } \\
\hline & education & both & work exp. \\
\hline Planning current and investment maintenance of port operations & $50 \%$ & $38 \%$ & $13 \%$ \\
\hline Compiling seasonal/annual work plans for port operations & $40 \%$ & $60 \%$ & $0 \%$ \\
\hline $\begin{array}{l}\text { Technical preparation, supervision and maintenance of port operations during / outside the } \\
\text { season }\end{array}$ & $71 \%$ & $14 \%$ & $14 \%$ \\
\hline Managing port operations employees and their training & $64 \%$ & $29 \%$ & $7 \%$ \\
\hline Participation in port operations design, construction, reconstruction, equipping and furnishing & $40 \%$ & $60 \%$ & $0 \%$ \\
\hline $\begin{array}{l}\text { Inspection of the safety of vessels and crew in the marina and of vessels' technical } \\
\text { documentation }\end{array}$ & $40 \%$ & $60 \%$ & $0 \%$ \\
\hline Development and management of vessel and yachtsmen databases & $33 \%$ & $67 \%$ & $0 \%$ \\
\hline Recognition and resolution of emergency and risky situations & $60 \%$ & $30 \%$ & $10 \%$ \\
\hline Expert knowledge & $40 \%$ & $60 \%$ & $0 \%$ \\
\hline Foreign languages & $0 \%$ & $100 \%$ & $0 \%$ \\
\hline Communication skills & $100 \%$ & $0 \%$ & $0 \%$ \\
\hline Organizational skills & $100 \%$ & $0 \%$ & $0 \%$ \\
\hline
\end{tabular}

Table 2.

Knowledge and skills for the second key task.

Marina business management and activities

MANNER OF KNOWLEDGE AND

SKILL ACQUISITION

education both work exp.

Annual business plan compilation

Organizational structure development (organization of work)

Human resources coordination

Knowledge of business economics

Supervision of results of marina operations

Services and competitive price development

Key market and sales management, guest satisfaction survey

Promotional plan development (advertising, PR, sponsorships, sales promotion, marketing)

Marketing strategy proposal, marketing plan development

Participation in marina construction and equipping

Database development

Foreign language

\begin{tabular}{|lll}
\hline education & both & work exp. \\
\hline $0 \%$ & $100 \%$ & $0 \%$ \\
\hline $0 \%$ & $67 \%$ & $33 \%$ \\
\hline $71 \%$ & $0 \%$ & $29 \%$ \\
\hline $9 \%$ & $64 \%$ & $27 \%$ \\
\hline $63 \%$ & $25 \%$ & $13 \%$ \\
\hline $50 \%$ & $25 \%$ & $25 \%$ \\
\hline $100 \%$ & $0 \%$ & $0 \%$ \\
\hline $15 \%$ & $62 \%$ & $23 \%$ \\
\hline $25 \%$ & $50 \%$ & $25 \%$ \\
\hline $0 \%$ & $100 \%$ & $0 \%$ \\
\hline $55 \%$ & $27 \%$ & $18 \%$ \\
\hline $57 \%$ & $14 \%$ & $29 \%$ \\
\hline
\end{tabular}


Table 3.

Knowledge and skills for the third key task.

FInancial and strategic planning of the marine

MANNER OF KNOWLEDGE AND

\begin{tabular}{|c|c|c|c|}
\hline & \multicolumn{3}{|c|}{ SKILL ACQUISITION } \\
\hline & education & both & work exp. \\
\hline Analysis, presentation and compilation of financial reports & $11 \%$ & $89 \%$ & $0 \%$ \\
\hline Allocation of financial and other resources & $33 \%$ & $67 \%$ & $0 \%$ \\
\hline Liquidity monitoring and cash flow management & $22 \%$ & $67 \%$ & $11 \%$ \\
\hline Review and compilation of medium-term and long-term financial plans & $20 \%$ & $80 \%$ & $0 \%$ \\
\hline Medium-term and long-term business performance analysis & $0 \%$ & $100 \%$ & $0 \%$ \\
\hline Proposing marina strategy and development & $43 \%$ & $29 \%$ & $29 \%$ \\
\hline $\begin{array}{l}\text { Investment plan assessment and compilation, identifying the most favorable sources of } \\
\text { funding }\end{array}$ & $25 \%$ & $50 \%$ & $25 \%$ \\
\hline Coordination and representation of the marina in front of financial and tax authorities & $0 \%$ & $0 \%$ & $100 \%$ \\
\hline Controlling & $0 \%$ & $100 \%$ & $0 \%$ \\
\hline Knowledge of economics & $0 \%$ & $100 \%$ & $0 \%$ \\
\hline
\end{tabular}

Table 4.

Knowledge and skills for the fourth key task

Communication and coordination with external (partners, guests) and internal (employees) MANNER OF KNOWLEDGE AND stakeholders

\begin{tabular}{|c|c|c|c|}
\hline \multirow[t]{2}{*}{ stakenolders } & \multicolumn{3}{|c|}{ SKILL ACQUISITION } \\
\hline & education & both & work exp. \\
\hline Knowledge and implementation of ISO ${ }^{1}$ standards and norms & $11 \%$ & $89 \%$ & $0 \%$ \\
\hline Identifying and resolving issues relating to service provision and quality processes & $85 \%$ & $15 \%$ & $0 \%$ \\
\hline Recognition of the needs of the local population & $100 \%$ & $0 \%$ & $0 \%$ \\
\hline Recognition of the importance of networking and regional cooperation & $60 \%$ & $40 \%$ & $0 \%$ \\
\hline Excellent knowledge of English and other foreign languages, communication skills & $10 \%$ & $90 \%$ & $0 \%$ \\
\hline Organizational skills and ability to manage larger groups & $75 \%$ & $25 \%$ & $0 \%$ \\
\hline $\begin{array}{l}\text { Cooperation with tourist agencies and tourist boards, development of the business partner } \\
\text { network (marina networking) }\end{array}$ & $70 \%$ & $20 \%$ & $10 \%$ \\
\hline Managing port operations employees and their training & $82 \%$ & $18 \%$ & $0 \%$ \\
\hline Charter research & $100 \%$ & $0 \%$ & $0 \%$ \\
\hline Marketing & $0 \%$ & $100 \%$ & $0 \%$ \\
\hline Sales skills & $0 \%$ & $100 \%$ & $0 \%$ \\
\hline
\end{tabular}

1. ISO-Interantional Organisation for Standardization. 
Table 5.

Knowledge and skills for the fifth key task.

Protection of the sea and the sea environment

MANNER OF KNOWLEDGE AND

SKILL ACQUISITION

education both work exp.

Knowledge and implementation of the $\mathrm{MARPOL}^{2}$ convention and any amendments thereof

$67 \% \quad 33 \% \quad 0 \%$

Familiarity with the systematic approach to environmental protection

Knowledge of EU regulations, norms and directives, as well as of the principles of

$40 \%$

$60 \% \quad 0 \%$

environmental protection

Monitoring of the maritime legislative framework and meeting the requirements relating to the health, safety and protection of the marine environment

Knowledge of regulations pertaining to hazardous materials and hazardous waste disposal in compliance with such regulations

Sustainable development planning and composing future pollution prevention plans

$\begin{array}{lll}80 \% & 0 \% & 20 \% \\ 67 \% & 33 \% & 0 \%\end{array}$
disposal

$20 \% \quad 80 \% \quad 0 \%$

$20 \%$

$80 \% \quad 0 \%$

Table 6.

Knowledge and skills for the sixth key task.

Improving the knowledge of maritime law and other relevant regulations

MANNER OF KNOWLEDGE AND SKILL ACQUISITION

education both work exp.

Implementation and knowledge of the domicile maritime law framework and accompanying international legal and EU regulations

Knowledge and implementation of the Maritime Code, Customs Act and Maritime Domain and Seaports Act

Implementation of commercial law

Knowledge of transport insurance

Recognition and application of classification society requirements

Keeping professional secrecy

Foreign language
$43 \% \quad 57 \% \quad 0 \%$

$17 \% \quad 83 \% \quad 0 \%$

$20 \% \quad 80 \% \quad 0 \%$

$0 \% \quad 50 \% \quad 50 \%$

$100 \% \quad 0 \% \quad 0 \%$

$50 \% \quad 0 \% \quad 50 \%$

$0 \% \quad 100 \% \quad 0 \%$

2. MARPOL-International Convention for the Prevention of Pollution from Ships. 
3.2.3. Correlation between key tasks and the knowledge and skills for the occupational standard of Maritime personnel Training and Education Coordinator

The following tables (7-11) illustrate the knowledge and skills required for the performance of each key task specific to the profession Maritime personnel Training and Education Coordinator. Similar as for results relating to the profession of Manager, a more detailed analysis of the required knowledge and skills, as well as of the manner of their acquisition are indicated in percentages in each individual table.

Table 7.

Knowledge and skills for the first key task.

Monitoring the need for education and training of new and existing maritime personnel

\begin{tabular}{|c|c|c|c|}
\hline \\
\hline & education & both & work exp. \\
\hline $\begin{array}{l}\text { Knowledge of the STCW }{ }^{3} \text { convention and amendments thereof, as well as of the manner of } \\
\text { promotion of maritime officers and maritime mechanical engineers }\end{array}$ & $55 \%$ & $45 \%$ & $0 \%$ \\
\hline Assesment of shipowners and training program user requirements & $90 \%$ & $10 \%$ & $0 \%$ \\
\hline $\begin{array}{l}\text { Familiarity with the dynamic nature of the maritime market and an understanding of the } \\
\text { forces shaping the maritime industry and activities }\end{array}$ & $100 \%$ & $0 \%$ & $0 \%$ \\
\hline $\begin{array}{l}\text { Analysis of the offer/demand ratio for specific types of maritime personnel on the maritime } \\
\text { market }\end{array}$ & $67 \%$ & $33 \%$ & $0 \%$ \\
\hline Knowledge of statistical methods used in the long-term planning process & $50 \%$ & $50 \%$ & $0 \%$ \\
\hline Knowledge and implementation of the $\mathrm{SMS}^{4}$ ordinance & $75 \%$ & $25 \%$ & $0 \%$ \\
\hline Risk assessment abilities & $75 \%$ & $25 \%$ & $0 \%$ \\
\hline Knowledge and implementation of ISO standards and norms & $33 \%$ & $67 \%$ & $0 \%$ \\
\hline Foreign language knowledge & $0 \%$ & $100 \%$ & $0 \%$ \\
\hline Expert knowledge & $0 \%$ & $100 \%$ & $0 \%$ \\
\hline Adjustment & $100 \%$ & $0 \%$ & $0 \%$ \\
\hline Team work & $100 \%$ & $0 \%$ & $0 \%$ \\
\hline Transfer of knowledge & $100 \%$ & $0 \%$ & $0 \%$ \\
\hline $\mathrm{MLC}^{5}$ & $0 \%$ & $100 \%$ & $0 \%$ \\
\hline
\end{tabular}

3. STCW-International Convention on Standards of Training, Certification and Watchkeeping for Seafarers.

4. SMS-Safety Management System.

5. MLC-Maritime Labour Convention. 
Table 8.

Knowledge and skills for the second key task.

Coordination and organization of specialized training programs

MANNER OF KNOWLEDGE AND SKILL ACQUISITION

\begin{tabular}{|c|c|c|c|}
\hline & education & both & work exp. \\
\hline $\begin{array}{l}\text { Exceptional communication skills when acting as an agent between the training center and } \\
\text { clients in need of training }\end{array}$ & $100 \%$ & $0 \%$ & $0 \%$ \\
\hline Methods of planning and scheduling of educational programs to optimize time utilization & $60 \%$ & $20 \%$ & $20 \%$ \\
\hline Maritime technical knowledge (ship class, type, intended use) & $40 \%$ & $40 \%$ & $20 \%$ \\
\hline Ability to assess the relevance and quality of a particular training program & $100 \%$ & $0 \%$ & $0 \%$ \\
\hline Business skills and ability to work under pressure & $0 \%$ & $0 \%$ & $100 \%$ \\
\hline Ability to manage large groups and recognize the needs of others & $100 \%$ & $0 \%$ & $0 \%$ \\
\hline Knowledge and implementation of ISO standards and norms & $25 \%$ & $50 \%$ & $25 \%$ \\
\hline Identification and resolution of issues relating to training program provision and quality & $100 \%$ & $0 \%$ & $0 \%$ \\
\hline Knowledge of national and international maritime regulations, conventions and declarations & $50 \%$ & $13 \%$ & $38 \%$ \\
\hline Resourcefulness & $100 \%$ & $0 \%$ & $0 \%$ \\
\hline STCW convention requirements & $100 \%$ & $0 \%$ & $0 \%$ \\
\hline Organizational skills & $100 \%$ & $0 \%$ & $0 \%$ \\
\hline Marketing knowledge & $100 \%$ & $0 \%$ & $0 \%$ \\
\hline Foreign languages & $100 \%$ & $0 \%$ & $0 \%$ \\
\hline Work under pressure & $100 \%$ & $0 \%$ & $0 \%$ \\
\hline
\end{tabular}

Table 9.

Knowledge and skills for the third key task.

Administration and maintenance of educational programs data

MANNER OF KNOWLEDGE AND SKILL ACQUISITION

Familiarity with the provisions of the ILO ${ }^{6}$ convention, the Labor Act and trade union demands education both work exp.

Knowledge of the components of the $\mathrm{WHO}^{7}$ and the $\mathrm{IMO}^{8}$ relating to the required

$25 \%$

$50 \%$

$25 \%$ international certificates

Knowledge and implementation of national legislation regulating the verification of authenticity of accompanying documentation and certificates

Creation of personal student progress portfolios

Computer skills in complex database maintenance, use of maritime computer programs

$67 \%$

$50 \%$

Knowledge of regulations from the field of adult education

Familiarity with the principles of lifelong learning

Knowledge of the STCW convention, as well as of the manner of promotion of maritime officers and maritime mechanical engineers

\begin{tabular}{|c|c|c|c|}
\hline Going into details & $100 \%$ & $0 \%$ & $0 \%$ \\
\hline Orderliness & $100 \%$ & $0 \%$ & $0 \%$ \\
\hline Business communication & $0 \%$ & $100 \%$ & $0 \%$ \\
\hline Knowledge of the MLC & $0 \%$ & $100 \%$ & $0 \%$ \\
\hline
\end{tabular}


Table 10.

Knowledge and skills for the fourth key task.

Education programs cost management

MANNER OF KNOWLEDGE AND SKILL ACQUISITION

Basic accounting knowledge

education both work exp.

Ability to plan future costs

$25 \% \quad 50 \% \quad 25 \%$

Ability to allocate and optimize the use of resources

$33 \% \quad 17 \% \quad 50 \%$

Compilation of a financial plan for a particular period

$67 \% \quad 0 \% \quad 33 \%$

Planning and anticipating trends on the maritime labor market from the aspect of

$40 \%$

$20 \%$
profitability

Ability to assess risky situations

$75 \%$

$5 \%$

$0 \%$

$25 \%$

Negotiation skills when contracting training courses

\begin{tabular}{|lll}
\hline $0 \%$ & $50 \%$ & $50 \%$ \\
\hline $100 \%$ & $0 \%$ & $0 \%$
\end{tabular}

Table 11.

Knowledge and skills for the fifth key task.

Cooperation with competent national authorities and international training service providers

\begin{tabular}{|c|c|c|}
\hline education & both & work exp. \\
\hline $64 \%$ & $18 \%$ & $18 \%$ \\
\hline $40 \%$ & $60 \%$ & $0 \%$ \\
\hline $88 \%$ & $0 \%$ & $13 \%$ \\
\hline $71 \%$ & $14 \%$ & $14 \%$ \\
\hline $100 \%$ & $0 \%$ & $0 \%$ \\
\hline $22 \%$ & $56 \%$ & $22 \%$ \\
\hline $100 \%$ & $0 \%$ & $0 \%$ \\
\hline $100 \%$ & $0 \%$ & $0 \%$ \\
\hline $100 \%$ & $0 \%$ & $0 \%$ \\
\hline
\end{tabular}

6. International Labour Organisation.

7. WHO- World Health Organisation.

8. IMO- International Maritime Organisation. 


\subsection{Key Competences for Lifelong Learning}

Key competences for lifelong learning are a part of generic skills considered necessary in a variety of different professions, defined in 2006 by the EU as competencies required for social inclusion, employment and lifelong learning. The last part of the questionnaire examined the extent to which work at the respective workplace required developed key competences for lifelong learning.

Apart from key competences for lifelong learning, the survey also examined other generic skills. The results (for both professions) indicate that the employers generally consider all such skills necessary.

Responsibility and focus on clients' needs are considered the most important for the profession of Manager $(M=4.64$, $\mathrm{SD}=0.68)$, with compassion $(M=3.89, \mathrm{SD}=0.74)$ getting the lowest average rating. Responsibility at the workplace $(M=4.48$, $\mathrm{SD}=0.58$ ) is considered the most important for the profession of Coordinator, with awareness of environmental protection getting the lowest average rating $3.54(\mathrm{SD}=1.10)$.

\section{CONCLUSION}

The implementation of the described project is compatible with the goals of the Strategy of Education, Science and Technology of the Republic of Croatia and the Croatian Qualifications Framework intended to establish a correlation between the labor market and educational programs at all levels. By establishing relations with key partners from the maritime sector, the Maritime Management study program will correlate with and become more responsive to the needs of the labor market through the development of occupational and qualification standards.

It should be noted that this is the first labor market research to deal with the needs of the employers, contents of a profession and workplace specification. The research results indicate that, in spite of the novelty of the professions, they have both been recognized by employers.
The research results indicate that the employers believe that the profession of Manager necessitates graduate university studies (Level 7), while the profession of Coordinator required undergraduate studies (Level 6).

The employers recognized the importance of generic skills, i.e. key competences for lifelong learning, stressing the focus on clients' needs as the most important competence for the profession of Manager, and responsibility at the workplace as the most important competence for the profession of Coordinator.

Well-conceived occupational and qualification standards are connected by learning outcomes. Qualification standards are defined on the basis of the knowledge and skills established by the applicable occupational standard, i.e. learning outcomes are defined as competences acquired through learning and proven by appropriate tests. The employers are thus also given an important role in the creation of educational programs, whereby a direct correlation is established between the educational system and the needs of the labor market.

\section{REFERENCES}

Anketa o standardu zanimanja, available at: http://www.upitnici.hzz.hr, [accessed 1 September 2015.].

Bartram, D., (2005), The Great Eight Competencies: A Criterion-Centric Approach to Validation, Journal of Applied Psychology, 90(6), pp. 1185-1203., http://dx.doi.org/10.1037/0021-9010.90.6.1185

Ministarstvo znanosti, obrazovanja i sporta, Poziv na dostavu projektnih prijedloga, Unaprjeđivanje kvalitete $\mathrm{u}$ visokom obrazovanju uz primjenu Hrvatskog kvalifikacijskog okvira, (2014), available at: http://wwwstrukturnifondovi.hr/ natjecaji/46, [accessed 12 January 2016.].

Ministarstvo znanosti, obrazovanja i sporta, Strategija obrazovanja, znanosti i tehnologije, (2014), Narodne novine, 124(2014), available at: http://narodne-novine. nn.hr/clanci/sluzbeni/2014_10_124_2364.html, [accessed 15 December 2015.].

Pomorski menadžment za 21. stoljeće, available at: http://www.pm21 $1^{\text {st }}$.eu, [accessed 15 Ocotober 2015.].

Smjernice za izradu standarda zanimanja, availabe at: http://www.kvalifikacije.hr, [accessed 14 December 2015.].

Zakon o Hrvatskom kvalifikacijskom okviru, (2013), Narodne novine, 22(2013). 